\title{
Technologies in Mathematics Lessons: What do Mathematics Teachers Say?
}

\author{
Maria Raquel Miotto Morelatti, Eliel Constantino da Silva, Débora Oliveira Medeiros \\ São Paulo State University, Brazil
}

\begin{abstract}
This article presents the results obtained during an investigation about the use of computers in the mathematics lessons from public schools, in Elementary Education II from Presidente Prudente, São Paulo State, Brazil and supported by the Program Acessa Escola, responsible for the provision of computer laboratories so that teachers could integrate the technologies into their practices. This investigation was developed under the research project "Mapping the use of information technologies in mathematics lessons in São Paulo State", financed by the Program Observatório da Educação (OBEDUC 2012) from the Coordination for the improvement of Higher Education Personnel (CAPES), an entity of Brazilian Government (Notice $n^{\circ} 049 / 2012 / C A P E S / I N E P$.) Results point higher use of technologies for geometry teaching, and according to the investigated teachers, which really matters, is not only having access to technologies, but know how to use them in order to provide opportunities to students in several situations.
\end{abstract}

\section{Some Considerations}

This article focuses on the reflection about the integration of Technologies with in the teaching education practices of mathematics teachers, from an investigation accomplished under the Brazilian program Observatório da Educação(OBEDUC) of the Coordination for the improvement of Higher Education Personnel (CAPES) that aims to foment researches in Educational area, capable of articulating post-graduation, bachelor's degree and elementary schools.

The investigation was carried out together with 21 mathematics teachers, of 30 state public schools under jurisdiction of the Regional Board of Education (DE) of Presidente Prudente, and that possess Elementary Education II and computer laboratories connected to the Program Acessa Escola. In a qualitative approach of research, it was aimed giving a voice to education professionals, such as principals and teachers, in order to familiarize with their conceptions, ideas and critics recurrent to the use of technologies in mathematics lessons and about the Program Acessa Escola, taking into consideration the labs' infra-structure, such as: number of school with internet access, number of computers into operation, software products and others. The data was collected through initial documents gathering, followed by meetings with the Board of Education representatives, visits to schools, analysis of the physical conditions of the laboratories and interviews with teachers, school managers and computer labs' monitors.

The state public schools possess computer laboratories that were equipped by the Program Acessa Escola, an initiative of the São Paulo State's Government that aims to implant computer laboratories or boosts the laboratories already available at public schools, promoting the digital inclusion of students, teachers and employees, so this investigation is characterized for verifying the use of these laboratories in mathematics lessons

The National Council of Teachers of Mathematics (NCTM) preconizes the following principles: "Technology is essential in teaching and learning mathematics; it influences the mathematics that is taught and enhances students' learning" [1].

And if we observe the human evolution we will see that:

Mathematics and technology were developed in a close association, in a relationship we could call symbolic. Technology, understood as convergence of knowledge (science) and making (technique) and the mathematics are intrinsic to the solidary search of surviving and transcending. Therefore, the generation of mathematical knowledge cannot be dissociated of the available technology [2]

This association of mathematical knowledge and technology make the learning focused: "On the generation of meanings, problem solving, students' mathematizations, use of representations, creation of socio-cultural norms in the classroom" [3] and requires investment on infra-structure to the lesson and access to information for teachers and students through technological resources [4].

Thus, it is necessary having conceptions about the integration of digital technologies in mathematics lessons [5], and understand "how learners construct mathematical ideas by drawing on the webbing of the particular setting which, in turn, shapes the way the ideas are expressed" [6]. 


\section{The computer laboratories and software products in mathematics lessons}

The use of technological tools in the activities of mathematics teachers constitute an educational form of assistance to students' learning, instrument (tool) of assistance for teachers when preparing their lessons, and a form of interaction and collaboration with other teachers and educational peers [7]. Among the various technological tools, the computer has detached due to its importance in promoting the teaching and learning in the mathematics lessons. [4] is clear when says computers has the

advantage of allowing an environment of interactivity between students and teachers, on the other hand, there is the need of having a computer laboratory structured with a propitious environment, and equipped with adequate physical space, ventilation and Internet in a way everyone can be connected simultaneously, with diversity of ideas, speed in exchanging information and reflections, what requires a dynamic thought of the teacher. (p. 4).

It is necessary being aware that the use of computer laboratories in mathematics lessons requires the construction of new educational structures, a new moment in the educative process [8]. It is a moment when the mathematics lesson becomes pleasant for students and teachers, with a laboratorial structure that provides a different experience of teaching environment, that allows significant learning and it is personalized for students.

The computer laboratory in the Mathematics lessons comprises not only the procedures of activities orientation, but also to the procedures of usage and construction of a teaching and learning environment, as well as follow up, exploration of available resources and communication among the different kinds of participants in the lesson [4]

This author, during an investigation accomplished with groups from the 1st Grade of High School testified that the mathematics lessons in the computer laboratories promote a significant learning, besides enabling the widening of concepts and knowledge about the contents approached in the lesson.

The process for choosing the educational software product to be used is pivotal; in order to assure that all the potential available in the laboratory contributes, in an effective way, to the learning process of students. This choice depends on the objective that is aimed to reach in the learning environment, the students' difficulties, and the teacher's analysis about the adjustment of the software to their goals in their teaching practices [9].
The use of educational software products allows the completion of unknown demonstrations, and also develop the necessary reasoning to formal demonstrations and of difficult comprehension [10], and still contribute, due to their dynamics, with the construction of mathematical concepts [11].

\section{Computer programs oh the Brazilian government in education}

Understanding the historical process here referred to Brazil, towards the governmental initiatives to insert computers in schools until the current governmental program of São Paulo State, named "Acessa Escola" is important, because it can be observed under what circumstances the current computer laboratories in public schools are. This historical process was described by various authors such as [12], [13], [14], [15].

With the coming of Seymour Papert e Marvin Minsky, in 1975, to the State University of Campinas (UNICAMP), started the first investigations about the use of computers in Brazilian education, using the programming language LOGO. Since this visit, initiatives started to be created following this tendency [16]

[...] at the beginning of the 80s there were various initiatives about the use of computers in education in Brazil. These efforts, allied to the ones that took place in other countries and to the interest of the Minister of Science and Technology (MCT) for dissemination of informatics in society, arouse the interest of the government and researchers of universities in the implementation of educational programs based on the computer use. This implementation took place with the first and second National Seminar of Informatics in Education, hold respectively at the University of Brasilia in 1981 and at the Federal University of Bahia in 1982. (National Seminar of Informatics in Education 1 and 2, 1982,) [12]

From the issues raised during, and after the I National Seminar of Informatics in Education, it was established programs such as the EDUCOM (COMputer in EDUcation), executed by the Especial Secretary of Informatics (SEI) and Ministry of Education and Culture (MEC), aiming to instruct researchers and professionals of public schools. For this purpose were created various centers in different universities throughout Brazil, fomenting researches towards introducing computers in education. This program allowed the creation of the Project FORMAR (Formar I - 1987, Formar II - 1989) with courses for teachers or professionals to specialize about informatics in education and share their knowledge with other people. 
In 1989, it was released by MEC, The National Program of Educational Informatics - via Proninfe, consolidating different developed actions, collaborating to creation of new laboratories and teacher's education [17], [13].

The National Program of Informatics in Education - PROINFO, was launched in 1997, by the Distant Education Secretary (Seed/MEC) with the goal of bringing educational digital resources and computers as pedagogical use to public schools of elementary education of the whole country, besides providing the necessary support to them.

In 1998, the state Secretary of Education of São Paulo created the program "A escola de cara nova na era da informática" (New school face in Informatics era) which provided more than 40 software titles to computer laboratories, approaching the several areas of knowledge. The ones related to mathematics are: Cabri II, Divide and Conquer, Factory and Supermaticas. Another governmental program held in 2000 in the State of São Paulo, is the "Acessa São Paulo" aiming to provide digital inclusion, social and intellectual development to all citizens through the information and communication technologies (TIC), internet accessand setting the called Municipal Posts, which are public spaces located, for example in libraries, and that are accordingly equipped with the TIC.

Finally, in 2008, it was created, by the Secretary of Education of São Paulo, the program "Acessa escola" toward education and schools, that aimed the digital inclusion of students, teachers and employees of state public schools, exchanging of ideas and construction of knowledge among teachers, between teachers and students and among students, by offering access to the TIC, monitors and training courses for these.

\subsection{Acessa Escola: governmental program of São Paulo State}

\section{The program Acessa Escola \\ of São Paulo State's Government, developed by the Secretary of Education, under coordination of the Foundation for the Development of Education (FDE), aims to promote the digital and social inclusion of students, teachers and employees of the state public schools, through the internet it enables the users to access the information technologies and communication to the construction of knowledge and social strengthening of school staff [18].}

Besides promoting the digital inclusion, it attempts to encourages the young to take part in the construction of new spaces inside schools, involving them in internship activities in the laboratories implanted in schools, it offers services such as, enabling teachers and students to use the computers to take distance courses and promote the exchanging of knowledge among students, teachers and employees.

The program also enables the elaboration of projects by teachers, monitors and others, which aim the training or specialization of teachers, creation of blogs for schools, or any other idea that involve the professionals of the school or related to it.

Regarding to the management, there is a local management made by school's representatives, such as teachers, students and employees on order to support the monitor in charge of the computer lab. The regional management in made by the Regional Board of Education (DE) that counts on the coordinator teachers and college interns responsible for the implementation of the Program in the schools. Finally the central management, constituted by the Secretary of Education and Foundation for Development of Education, must direct the insertion of computer in state public schools, follow-up and evaluate the Program in these unities of High School.

The computer laboratories of the Program Acessa Escola have some usage rules, such as impossibility of usage in case of the absence of the responsible intern to liberate the access, and for the access, it is necessary a previous register, whoever student, teacher or employee, that is made with the number of the Academic Register (RA) or General Register $(\mathrm{RG})$ of the user. When registering, the intern is responsible to explain the rules and make people aware of the adhesion form, and when the user is a minor, this form must be assigned by their responsible. The computers are free to use, but present some restrictions. The user has access liberated for 30 minutes, allowed to use as much as he want as long there are no more other users waiting to use the machine. The computer laboratories are opened during school time and have an intern for period, who must work for 4 hours every day. This way, if any teacher desires to take a group to the lab, it must have been done an appointment and have the students already registered in the computers.

The program possesses monitors or interns who perform the program. They are students regularly enrolled at $1^{\text {st }}$ or $2^{\text {nd }}$ grade of High School in state schools and take part in a selection test that evaluate general knowledge, such as logical thought and language usage, and also the basic knowledge of informatics and its resources. For selection and designation, it is given preference for students from that school, but when there is no one, it is named a student from another school, but still belonging to the regional Board of Education (DE), respecting the test classification. It is offered training courses for the selected monitors, that may take place in presence courses in the DE or online. This participation happens in three modules, according to the Manual of the Director Program: The first aims to transmit the most important information about the 
Program and how it works. The second approaches the different form of usage and possibilities of internet, and presents as main theme Safe Internet and Web 2.0. The third and last module encourages the accomplishment of individual or collective projects such as the above mentioned, creating blogs for the school, training projects for teachers, etc. The internship is supposed to last for one year, possible to extend for one more year, four hours a day of paid internship that must take place in an extra-class period; different from the one the intern is enrolled as student. The intern's job is helping teachers and students toward the technological resources.

The computer laboratories are managed by the software Blue Control that

facilitates the class organization, once it offers resources to liberate the use of computers; organize waiting lists and register technical problems in the system. Besides, it contributes to the communication between the interns and the Coordination of the Program or the Board of Education, once this resource is used to transmit notification or notices about the Program or about the room itself. [..] It is also possible to turn on, turn off and visualize all computers in the room, enabling the block of any undue action of users" [16].

The laboratories also possess the software $B u e L a b$, that enables teachers to enrich their lessons with resources and interactivity [16].

According to the Secretary of Education of São PauloState. There were 11 thousands interns in the computer laboratories who received a scholarship, 80 thousands new computers, that if compared with the last surveying of 2013, when there were 62.3 thousands machines, comes to a total of 142.3 thousand computer available in schools. There was an increase in the number of participant schools, from 3.715 to 4.168 schools with approximately 3.8 million students registered.

The platform that the Program Acessa Escola operates in the computers of schools, possesses several software products installed, not only for mathematics, but also for all the other subjects such as physics, Arts, Languages, etc, all available for teachers to explore for free. For mathematics lessons there are specifically:

- GeoGebra: Allows generating graphics, animations, working with geometry concepts, geometric figures and even derivatives. This software also has an online page with explanatory videoclasses about several mathematics contents.

- Graphmatica: generator of graphics and functions of a variable, besides calculating derivatives, Integral calculus, etc.

- Poly1.12: allows visualizing polyhedrons and their planning, enabling printing these planning and rebuild them.
- Scratch: A more recent version of Logo, it introduces a simpler programming language and enables explore geometry, logics, among other concepts.

- Tess 1.75: Works the symmetry and different surfaces, allowing the creation of symmetric figures that remits to Escher' paintings.

- Torre de Hanói: it is a problem that must be played to be solved, or it can be used geometric progression to solve the problem.

- Winplot: enables the plotting of curves and surfaces.

- Wolfram CDF Player 9: graphics, analysis of statistical data, number theory, among numerous others.

\section{The use of computer laboratories and software products in teaching of mathematics by interviewed teachers}

Only $2(9.5 \%)$ out of the 21 interviewed teachers do not use the computer lab in their teaching practices due to the bureaucracy required by the program, it is time consuming due to the fact of depending on appointments, the presence of the monitor in the lab for its use, and the responsibility that rely on them in case of any damage to the machines caused by students. The big quantity, represented by 10 teachers $(47.6 \%)$ sometimes use the lab, the maximum of three times a year. However, an also expressive quantity within our sample, represented by 9 teachers $(42.9 \%)$, often use the lab, at least once a month, only depending on the content studied

Most of the software products use is for mathematical contents that allow the visualization and manipulation of comprehension rules and properties of a determined issue, for example, the study about the periodicity of a trigonometric function, relation among coefficients, graphics of the first degree equations, among others

However, this use does not always happen under good physical conditions. There are teachers using the technological resources to teach mathematics in laboratories with only 5 computers available, while there are teachers who use laboratories with 18 computers. In total, there are 394 computers distributed among the visited schools, with an average of 15 computers per school, and there are also a total of 27 computers which cannot be used due to technical defect, lack of accessories or problems in the system

The discrepancy among schools toward the use of Technologies in the process of teaching and learning of students comprises as well, the structure of the physical space that need to be adequate for the accomplishment of the activities [13]. There are schools with inappropriate physical space whereas 
there are schools with a wide, appropriate, and well equipped space. Some images of these labs illustrate such situation that is cited by the teachers as discouraging to the integration of technologies to their practices

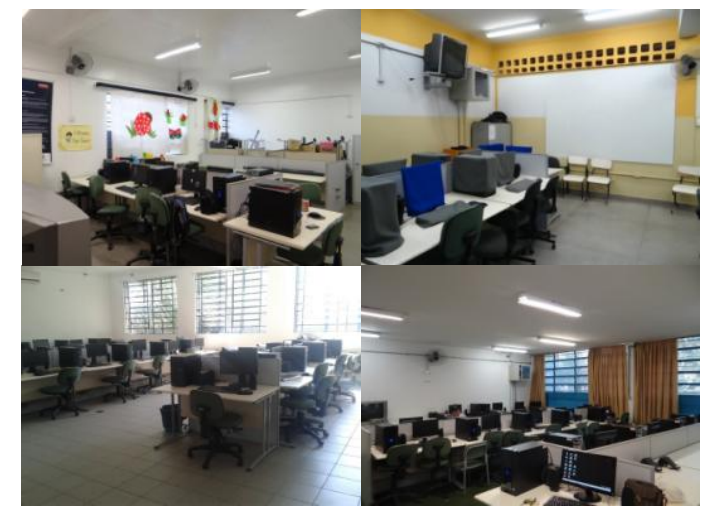

Figure 1. Computer Laboratories of state public school entailed to the Program Acessa Escola, participants of this research

About the use of software products, we found teachers using software even with few machines available, which reveal an acceptation and awareness of the potentialities of this use to the learning of students and the importance of having the Technologies integrated in the teaching practices of the mathematics teachers

Software products most used are GeoGebra, Poly and Cabri. A lot of the software products that are available by the program Acessa Escola in the computers of the laboratories are not used by these teachers, what allow to inquire about teacher's knowledge about these software products, their existence, functionality and usage. In this sense, [16] is clear when states

it is pivotal the teacher has technical knowledge about the software products, knowledge about the possibilities and different approaches of the pedagogical use of the computer for the teaching and learning of mathematics, and also how to organize an activity and integrate it to the curriculum (p.41)

Still about this use of technologies in mathematics lessons, we selected some testimonials of mathematics teachers, described hereinafter, named in alphabetical order of the school names, in order to better understand their conceptions about this use

[...] I've already used it. At least once a week. I worked with matrices [...], in the second grade of High School. The software brings the content, so I quit the textbook because I didn't need it. I presented the content and after they did the exercises in class. I only completed the information. [I also] worked with functions and multiplication to fill up a multiplication table. (Teacher from school number 10)

[The use] depends on the content, if it is statistic I use the whole month, for other contents, at least once a month. [with the software] Flash, I work with movement, throughout the internet. [also], graphics, statistics, area and volume (teacher from school number 3)

I only used the computer laboratory this year with the Elementary School groups. The High School groups are too numerous, about 40 students, and this make it difficult, there are always a computer that does not work. But, with the Elementary school groups it was very good, I took the seventh grade [to the laboratory], [...] we watched a video that is part of a project I developed with them, about recycling, so we watched the film: "The Island of flowers", I agreed with the intern, who downloaded the video, it was perfect, it really worked. They brought earphones, it really worked! In another occasion we worked with games involving multiplication tables, so I selected some links and wrote them on the board, I develop some charts that they should fill up in pairs, they should fill up each other's chart with a number of correct answers, it was also nice. Elementary School always embraces the ideas, they take the plunge in everything you propose, so everything is new for them, for High School it is more complicated. So, it was really nice, these are two examples of what we did. The contents we use to work are..., in this case the High School watched this video and worked with multiplication tables. In other situations I have been there with them, we did not have time to build graphics and tables using the EXCEL, it is something that can be very well explored...but it has taken a long time I cannot do it. In this project we developed, they brought some containers for us to send to recycling, so they build charts and work on it, they built bar graphics and pie charts. Then, they did it on the paper, using protractor, all very beautifully. But it would have been nice to have explored this there, in the computer lab, but we did not have time (teacher from school number 18)

We used the lab when we worked with Cartesian plan. The content was worked in the classroom and after they were put in the informatics, the teaching (teacher from school number 16)

[I used software] of geometrical solids...platonic solids, prism...is it Poly?! The intern worked with it, assembling, 
counting corners. And with the sixth grade it was with the Super Logo (teacher from school number 8 )

All the problematic context of the physical structure of the laboratories described along this topic is noticeable in teacher's speeches from school 18, it does not prevent them from using the technological resources in mathematics lessons, but it is still a very initial use. The speech of the teacher from school 10 intensifies, the already said, about the advantages of having the technologies as allied to the teaching process, and meets the ideas of [5] of having concepts about the use of technologies in mathematics lessons

\section{Conclusions}

It is realized that computer laboratories enrich the lessons and teachers are already losing their fears and distrusts, taking risks with new lessons and new technologies. They use software or sites that enables to teach or, at least, consolidate the contents studied in classroom, but in a much more attractive way for students, contributing for learning, even though the physical structures of laboratories are not the adequate, contradicting what the responsible representatives of the program state about their purpose: provide an adequate physical structure of the computer laboratories for educational use, in other words, we cannot talk about the use of technologies in mathematics lessons, here namely computers, if we do not have an adequate physical structure which assure this using. But it is noticeable the attempt and effort of these teachers to integrate the technologies in their teaching practices, which shows the importance of having them in school context. But, these reports also inquire us about the results of this usage on the learning of students: Has it promoted changes or they are just using the equipment? As the mathematics teachers who took part in the research expressed, the important is, not only having access to technologies, but also know how to use them to transform the teaching in such a form it provides for students, opportunities to several situations

It is also realized, in the teacher's speeches, the same findings that [4] obtained during an investigation accomplished with students from High School, cited in this article.

It was possible to notice that the program Acessa Escola is an initiative that came to add value towards the use of technologies in the mathematics teaching, but its structure requires some changes and there are few teachers who use it in their teaching practices.

Finally, it is observed that most of the teachers and monitors do not have the knowledge of the software products already installed in the computers of the laboratories and do not know how to use them in class context. It is concluded that there is a lack of training for teachers to learn how to use new software products and insert them into their practices, promoting changing in students' learning.

\section{Financing}

Coordination for the improvement of Higher Education Personnel (Notice $n^{\circ}$ 049/2012/CAPES/ INEP).

\section{References}

[1] NCTM (2000). Principles and Standards for School Mathematics. Reston, VA: National Council of Teachers of Mathematics.

[2] D'Ambrosio, B. (1996). Mudanças no papel do professor de matemática diante de reformas de ensino. Encontro anual de professores de matemática (Comissão Organizadora do ProfMat 96 ed). Lisboa: Associação de Professores de Matemática, pp 15-23

[3] Kalogeria, E., Kynigos, C. \& Psycharis, G., (2011).Teacher's designs with the use of digital tools as a means of redefining their relationship with the mathematics curriculum.Teaching Mathematics and Its Applications, 31, 31-40 .

[4] OLIVEIRA, C. A. (2010). O laboratório de informática como apoio ao processo de ensino e aprendizagem nas aulas de matemática. $3^{\circ}$ Simpósio hipertexto e tecnologias na educação - redes sociais e aprendizagem (Anais eletrônicos). Recife: UFPE, pp. 1-17.

[5] Weigand, H.-G., (2013). Looking back and aheaddidactical implications for the of digital technologies in the next decade. Teaching Mathematics and Its Applications, $33,3-15$.

[6] Noss, R. \& Hoyles, C., (1996) Windows on Mathematical Meanings: Learning Cultures and Computers. Dordrecht, TheNetherlands: KluwerAcademic.

[7] Ponte, J. P.; Brocardo, J.; Oliveira, H. (2003). Investigações Matemáticas na Sala de Aula. Belo Horizonte: Autêntica.

[8] Oliveira, R. M. C., (2007). Aprendizagem mediada e avaliada por computador: a inserção dos blogs como interface na educação. Avaliação da aprendizagem em educação online(M Silva \& E Santos orgs.). São Paulo: Edições Loyola, pp.333-346.

[9] Gomes, A. S., Castro Filho, J. A., Gitirana, V., Spinillo, A., Alves, M., Melo, M.\& Ximenes, J. (2002). Avaliação de software educativo para o ensino de matemática.WIE 2002 Workshop Brasileiro de Informática Educativa. Florianópolis: SBC, pp. 1-8 .

[10] Scheffer, N. F. \& Sachet, R. (2010).Softwares matemáticos: investigação, conjecturas e conhecimentos. Revista Ciência e Tecnologia, 10, 49-224. 
[11] Piccoli, L.A.P., (2006).A construção de conceitos em matemática: uma proposta usando tecnologia de informação. Dissertação mestrado, Pontifícia Universidade Católica do Rio Grande do Sul, Brasil.

[12] Valente, J. A., (Org) (1999). O computador na sociedade do conhecimento. Campinas: Unicamp/NIED

[13] Borba, M. C. \& Penteado, M. G., (2003). Informática e educação matemática. 4a ed. Belo Horizonte: Autêntica

[14] Vieira, M. F., (2011). 25 anos de informática na educação brasileira: avanços e retrocessos. Simpósio brasileiro de informática na educação (Anais SBIE).Aracaju: SBC, pp. 1596-1599.

[15] Godoy, K. A. E., Silva, F. S., (2012). Análise inicial da recontextualização da prática pedagógica do professor por meio do uso do laptop educacional em sala de aula. Congresso internacional de tic e educação. Lisboa: Instituto de Educação da Universidade de Lisboa, pp. 252 262 .

[16] Oliveira, F. T., (2014). A inviabilidade do uso das tecnologias da ifnormação e comunicação no contexto escolar: o que contam os professores de matemática?. Dissertação mestrado, Universidade Estadual Paulista, Brasil.

[17] Tavares, N. R. B., (2002). História da informática educacional no Brasil observada a partir de três projetos públicos. São Paulo: Escola do Futuro, pp. 1-3.

[18] São Paulo, (2008). Programa Acessa Escola. Inc. http://acessaescola.fde.sp.gov.br/ [acessado 30 março 2015] 